\title{
BRITISH AND ROMAN NAMES FROM THE SULIS-MINERVA TEMPle: Two SOLUTIONS TO AN OLD PROBLEM*
}

\author{
TATYANA A. MIKHAILOVA
}

\section{Introduction}

According to Toporov, introducing a personal name into a charm is mandatory: "The text of a charm is a mere text and nothing more, until a name is incorporated into its large and immutable body. Only by adding the name and by pronouncing it does a verbal text turn into a ritual performance, that is, into an actual charm that works as such" (Toporov 1993: 100).

This rule seems actually to be observed invariably, although some specific cases are somewhat challenging when it comes to interpretation (for instance, the charms where, rather than a personal name, the first person is used). Multiple collections of charm texts, if this interpretation is correct, are not actual charms by themselves but rather raw material for performing charms which can only 'work' after the charmer has pronounced (or written) the name. A charm-text without the subject's name can be only seen as potentially magical - this is why Gager in his book on ancient tablets (Gager 1992) introduced the notion of a 'recipe', that is, a magical text which is not immediately magical but rather becomes so after the insertion of the name. Such 'recipes' were widespread in the Graeco-Roman world, and many of them survived.

Drawing parallels between oral charms and Greek or Roman magic tablets would be quite legitimate. Defixiones (Greek katadesmoi) were also name-oriented, so that the text itself mattered little because the very act of inscribing the name on a tablet suggested, by default, that that person had been cursed. Moreover, the person being cursed had to be specified as accurately as possible, and, in order to achieve this goal, the object's mother was mentioned in place of a formal patronymic, according to the principle mater certa, pater incertus. As Audollent pointed out more than a century ago, mentioning the name of the object's mother first is characteristic of all curse tablets: "mentioning the name of the mother would specify the enemy's identity" (Audollent 1904: lii). The most frequent formula was "[the name of the person], son/daughter of [a female name]' or '[the name of the person], born

\footnotetext{
* This research is supported by the Russian Foundation for Basic Research, project № 13-0600086.

${ }^{1}$ All translations of original text into English were done by the author unless otherwise stated.
} 
by [a female name]'. In some records of Russian charms, there occurs a similar formula, of the type 'Ivan, son of Matryona'.

Charms are also related to defixiones in the way their structure follows a single and unified genre pattern. Kagarov, a Russian expert on defixiones, drew attention to their resemblance to charms, noting that "[m]any of the extant tabellae defixionum show such close resemblance to each other that they could well have been written [...] by the same person following a single cliché" (Kagarov 1918: 24). A nearly identical observation, but applied to oral Slavonic charms, is made by Poznansky (who was, coincidentally, writing this at the same politically unstable time in Russian history): "There is not a single genre of folklore text as much dominated by clichés as charms. [...] Most charms are created according to a fixed system, employing a certain set of devices" (Poznanskij 1917: 75).

\section{An "old problem"}

However, in many cases inserting a name (subject name) into the charm is impossible, because it is not known either to the charmer or to his/her client, as the charm is not targeted against a particular person. This is the case with charms against thieves, which are quite widespread. Charms of this type are generally referred to as 'justice prayers'.

The first known Latin tabella defixionum of this type was found in 1972, in Italica, Spain. Here is the text with a rough translation:

Domna Fons Foyi [...] ut tu persequaris tuas res demando quiscunque caligas meas telluit et solias tibi illa demando (ut) illas aboitor si quis puela si mulier siue [ho]mo inuolauit [...] illos persequaris.

O Mistress Spring Foyi [...] I ask you to track down your possessions. Whoever has stolen my shoes and sandals I ask that you [...] whether it is a girl, a woman or a man who stole them [...] pursue them.

(Versnel 1991: 60)

Calling the stolen sandals the 'possessions' of Mistress Spring Foyi may seem baffling to a modern reader, yet it is fully explicable given that the deity was believed to own the objects entrusted to her or brought under her protection.

Many lead tablets of the same type - aimed at getting back one's stolen properties - are known from the earlier Greek tradition. Compare, for instance, the tablet ( $1^{\text {st }}$ century B.C.?) found in 1957 on the island of Delos. Its text pleads to the gods to direct their fury against the unknown individuals who had stolen the client's necklace (the client's gender is unidentifiable):

\footnotetext{
${ }^{2}$ For the history of the term and of research on this category of tabellae, see Versnel 1991.
} 


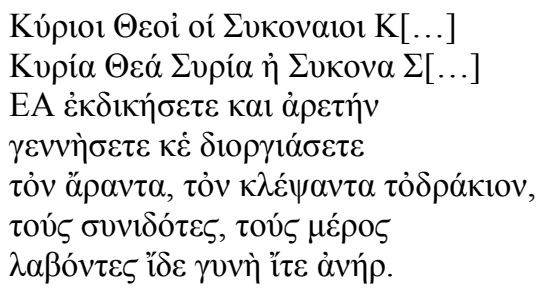

Lords gods Sykonaioi, Lady goddess Syria Sykona, punish, and give expression to your wondrous power and direct your anger to the one who took away my necklace, who stole it, those who had knowledge of it and those who were accomplices, whether man or woman.

(Jordan 1985: 158)

\section{Temple of Sulis Minerva in Bath}

Tablets with 'justice prayers' were found in abundance during the excavations at the Bath site of the Gallo-Roman temple dedicated to the goddess SulisMinerva (see Tomlin 1988). This site, with its natural hot spring that to this day is believed to have healing properties, was already a site of worship in the pre-Roman period and was associated with the goddess Sulis, whom the Romans would later identify with Minerva. At Bath, some time in the fifteen years after the rebellion of Boudicca, work began on the grand complex of baths and temple, "in which a deliberate attempt seems to have been made to do spectacular honour to a native cult by amalgamating it publicly with one of the greatest Roman deities in the new worship of Sulis Minerva, rather than to obliterate or downgrade the British element" (Salway 1993: 87). Later the temple was enlarged and decorated with statues. "Visited by many thousands of tourists today, Roman Bath was also, as is proved by inscriptions on stones from the area, visited by travellers from far and wide during the glory years of the Empire" (Mees 2009: 30). This place, known in Latin as Aquae Sulis, became a pilgrimage site for both Romans and British nobles. People would spend much time there, because the belief in the healing value of the spring still lingered, despite the fact that its visitors changed their faith. At the same time, some Romans would preserve the older belief that Sulis, the patron deity of the spring, was herself the healer. So, while the temple would still receive the worshippers of the ancient deity with their supplications, other people could simply take a bath and believe (quite justly) that it was good for their health.

Among the abundant finds unearthed by archaeologists at the site of the spring, ${ }^{3}$ which included more than 12,000 coins along with images of body

\footnotetext{
${ }^{3}$ The excavation was mainly performed in 1979-80 (for details, see Cunliffe 1995), yet some isolated objects had been discovered earlier.
} 
parts believed to have been healed by the goddess, 130 lead tablets with a variety of inscriptions were discovered.

\section{3. "Justice prayers" of Bath}

Along with name lists and commendations addressed to the goddess, there is a considerable proportion of tablets that can also be categorised as justice prayers. Their authors address the goddess Sulis in order to secure the return of stolen objects.

Compare, for instance

Docilianus Bruceri deae sanctissimae Suli devoveo eum qui caracellam meam involaverit si vir si femina si servus si liber ut [...] dea Sulis maximo letum adigat nec ei somnum permittat nec natos nec nascentes donec caracallam ad templum sui numinis pertulerit.

Docilianus (son) of Brucerus to the most holy goddess Sulis. I curse him who has stolen [? - T.M.]) my hooded cloak, whether man or woman, whether slave or free, that $[\ldots]$ the Sulis inflict death upon $[\ldots]$ and not allow him sleep or children now and in the future, until he has brought my hooded cloak to the temple of her divinity.

(Tomlin 1988: 122)

or

deae Suli Minervae Solinus dono nutnini tuo maiestati paxsam balnearem et palleum nec permittas somnum nec sanitatem [...] ei qui mihi fraudem fecit si vir si femina si servus si liber nissi se retegens istas species ad templum tuum detulerit...

Solinus to the goddess Sulis Minerva. I give to your divinity and majesty my bathing tunic and cloak. Do not allow sleep or health to him [...] who has done me wrong, whether man or woman, whether slave or free, unless he reveals himself and brings those goods to your temple...

(Tomlin 1988: 150)

What is remarkable is the formulaic nature of these texts, which differ in the object stolen, yet are almost identical in how the supposed thief is described: 'whether man or woman, whether slave or free...'

Generally, this type of justice prayer is modeled according to the following pattern:

- the owner's name;

- invocation of a deity;

- details of a (possible) theft, specifying the object;

- a quasi-naming formula ('whether slave or free, man or woman, boy or girl' etc.); 
- threats (to prevent the thief from eating, drinking, urinating and defecating; to deprive him of sexual potency; to make him/her sleepless and restless; to make him/her bleed etc.);

- the request ('until he/she returns the named object to the owner').

This scheme is not necessarily fully represented in every instance.

All of the known inscriptions differ in handwriting, which indicates that "written pages or preparatory models used in the manufacture of the tablets may have been prepared by professional curse-composers, but the individual cursers (or commissioners) of the defixiones were required to write the texts onto the specially created lamellas themselves" (Mees 2009: 32-3). It seems plausible to suggest that both the formula relating to the thieves and the list of curses intended to affect them in the event that they did not return the stolen property circulated in oral tradition and had their origin in folklore, that is, they were incorporated into the background knowledge of any person belonging to this culture.

The abundance of such tablets in the temple of Sulis Minerva is hardly surprising: according to Roman custom, bathers would store their clothes in special changing rooms (apodyteria) which, though they were equipped with a sort of shelving, were not locked. Invoking the goddess Sulis suggests, on one hand, that she was personally expected to take care of the possessions 'entrusted' to her. On the other hand, as Tomlin points out in his preface to the edition of the texts, those put in charge of the belongings were mostly slaves who would not infrequently fall asleep or even sell the clothes and the jewelry themselves and then claim to have been asleep or to have neglected their duties. In any event, the owners of the belongings actually believed that the goddess Sulis would look after them herself, or, rather, that she would personally punish the thief if the valuables were stolen.

\section{4. "Subject names" in Sulis curses?}

The explainable absence of subject names in these texts seems to indicate that they were replaced in the "charms" (Graeco-Roman defixiones being indeed charms) by the formula identifying the potential victim as "the one who has stolen my property'. Therefore, the invariable rule of introducing a personal name into the body of the charm, predicted by Toporov, seems to be fulfilled. It is also worth noticing that the Latin nomen had a broader meaning than just 'personal name' - it also meant 'identity' (represented in a name). In the light of this fact, consider a comparable curse against an unspecified thief, found on the foreshore of the Hamble Estuary, Hampshire: 
domine Neptune, tibi dono hominem qui solidum involavit Muconi et argentiolos sex. ideo dono nomina qui decepit, si mascel si femina, si puuer si puuella. ideo dono tibi, Niske, et Neptuno vitam, valitudinem, sanguem eius qui conscius fueris eius deceptionis. animus qui hoc involavit et qui conscious fuerit ut eum decipias. furem qui hoc involavit sanguem eiius consumas et decipias, domine Neptune.

Lord Neptune, I give you the man who has stolen the solidus and six argentioli of Muconius. So I give the names who took them away, whether male or female, whether boy or girl. So I give you, Niskus, and to Neptune the life, health, blood of him who has been privy to that taking-away. The mind which stole this and which has been privy to it, may you take it away. The thief who stole this, may you consume his blood and take it away, Lord Neptune.

(Bowman et al. 2)

We still have not got any universal pattern of introducing personal names into the text, which could be deduced from charms against theft. Moreover, as regards the tablets from the Sulis Minerva temple, I have to point out that in some cases the text consists entirely of names (or name lists). Tomlin believes them to be the names of the suspects, yet I tend to interpret them as the names of the victims. This uncertainty led me to take a closer look at the corpus of 130 tablets.

\section{Tomlin's corpus}

First of all, one has to notice that the number 130 refers to the total amount of finds and not of the texts preserved. 56 tablets survive in fragments that are nearly illegible, and some of them are blank: these could be spaces left for inscriptions, which were never used (Nos. 117-120, 123-130). Seven are what can only be deemed quasi-texts, representing wavelike lines or scratches that look like letter imitations (fig. 1). Tablets of this kind could possibly be explained by the charmer's illiteracy: the illiterate charmer either pretended to write down a text in order to avoid admitting his or her illiteracy or believed that Sulis would be able to understand what she was expected to do. In the latter scenario, the very act of scribbling on the tablet and throwing it into the well was sufficient. Eight tablets contain only name lists (from two names up to eleven).

Of the remaining 59, no. 1 is an alphabet written in capitals; no. 14 (fig. 2) is an undecipherable text which some scholars assume to be British (Tomlin, however, disagrees, stating that even a Briton would attempt to write in Latin: "Sulis understood Latin, the formulas were all Latin, anyone who was able to transcript Celtic would also know Latin, to be able to read and write at all" (Tomlin 1988: 129); no. 16 is the well-preserved yet apparently unfinished text nomen furis qui, 'The name of the thief who ...', which I interpret as a 
'recipe' rather than a true charm; nos. 27 and 28 contain no more than fragmented words hard to interpret (vendi, er); no. 35 is a mere invocation of revenge 'on those who have done (me) wrong'; ${ }^{4}$ similarly, no. 37 is a typical curse tablet bearing on one side a name list and on the other side the curse illorum anima lassetur, 'May their life be weakened' (Tomlin 1988: 156); no. 40 may also be a conventional defixio aimed against calumniators. ${ }^{5}$

No. 94 (fig. 3) addresses the goddess Sulis in order to corroborate a particular oath:

Uricalus Docilosa uxor sua Docilis filius suus et Docilina Decentius frater suus Alogosia nomina eorum qui iuraverunt ad fontem deae Sulis pridie idus Apriles quicumque ille periuraverit deae Suli facias illu, sanguine suo illud satisfacere.

Uricalus, Docilosa his wife, Docilis his son and Docilina. Decentinus his brother, Alogiosa: the names of those who have sworn at the spring of the goddess Sulis on the 12th of April. Whosoever has perjured himself there you are to make him pay for it to the goddess Sulis in his own blood.

(Tomlin 1988: 226)

As Tomlin pointed out, "this text is unique in being, not a curse tablet, but a sanction against perjury which accompanied an oath sworn at the spring of Sulis (the only time this phrase occurs). It is the first epigraphic evidence of a belief attested in literary sources, that certain hot springs and seething pools punished perjury" (Tomlin 1988: 226).

Tablet no. 18 is an object standing quite apart from the whole group, being a round bronze plaque with a loop on its edge and bearing a British text which will be discussed in more detail later.

No more that 49 out of 130 tablets can be categorised, therefore, as attempts to regain property or keep it safe, and, of those 49,24 can only be classified as such through guesswork, because, although either the invocation of Sulis legible, or formulae like 'slave or freeborn' partially preserved, or the word 'stolen' or some cursing formula like 'neither eat, nor drink, nor sleep, nor defecate until...' visible, the texts are badly damaged. Therefore, we are left with only 25 relatively complete texts doubtlessly concerning thefts, which is nonetheless sufficient to make some generalisation and/or draw some conclusions.

\section{How to curse a thief}

In Tablet no. 10 (fig. 4) cited above (one of the best-preserved and the most calligraphic), the verb referring to violation is involaverit, either the perfect

\footnotetext{
${ }^{4} \mathrm{Cf}$., however, no. 32 where the 'wrong' is specified as stealing a tunic.

${ }^{5}$ The text is barely legible, yet the words qui calamea can be made out.
} 
conjunctive or future II of involo 'steal, abduct, carry away'. The second version is more likely; that is, the message does not refer to some unknown individual having stolen the cloak (as Tomlin interprets it), but rather to Docilianus' putting the person who would steal his cloak into the custody of Sulis. This changes the inscription's pragmatics crucially. Tomlin claims that "a case can be made here for perfect subjunctive within a clause subordinate to an indirect command" (Tomlin 1988: 123), that is, translating these forms as 'if he had stolen' rather than 'if he steals'. I am not sure whether this interpretation is correct. Preventive texts of this kind are attested since earliest times. In Germanic culture, caskets holding jewelry were inscribed with runes representing distress or ailment, in order to ward off thieves. In modern-day Germany, there is still a practice of putting plaques with the formula Wer (hier) klaut, stirbt!, 'Who (here) steals, will die', in places which cannot be constantly guarded.

Tomlin, who claims that all the inscriptions on tablets were written post factum, suggests that they were modelled after inscriptions protecting tombs from desecration, where the same tense is used. Cf. the examples cited in his own work:

qui me (commoverit), habebit deos iratos et vivus ardebit, 'who will move me, will have deities in anger and will be burned alive'

qui hoc titulum sustulerit, habeat iratas unbras, "who will steal this plate, will have ghosts in anger'

qui hic mixterit aut cacarit, habeat deos superos et inferos iratos, 'who will urinate or defecate there, will have deities of the heaven and of the hells in anger'

(Tomlin 1988: 66)

Yet, contrary to his claim, the inscriptions cited by him are of a preventive nature!

The analysis of the corpus revealed that in 13 cases the verb used to describe the theft of the object was used in the past tense (mostly involavit, but sometimes fraudem fecit 'made damage' and perdidi 'I lost'). In 10 cases future II was used (involaverit, furaverit; Nos. 10, 11, 15, 34, 38, 61, 63, 66, $98,99)$. Two cases are unclear because the verb is omitted. Of the ten tablets which can be categorised as 'preventive', only five bear legible names of possible victims, and all these names are recognised by Tomlin as British (Docilianus, Docca, Lovernisca, Cantissena, Demiorix). ${ }^{6}$

\footnotetext{
${ }^{6}$ The range of British names is not limited to this list: more of them are found in tablets containing name-lists only.
} 
For example:

No. 10:

Docilianus Bruceri deae sanctissimae Suli devoveo eum qui caracallam meam involaverit...

(Tomlin 1988: 122)

This is translated by Tomlin as 'Docilianus, son of Brucetus to the most holy goddess Sulis, I curse him who has stolen my cloak' (Tomlin 1988: 122), but as 'who will steal my cloak' in my translation.

No. 99 - Theft from a house:

execro qui involaverit qui Deomiorix de hospitio suo perdiderit quicumque res deus illum inveniat sanguine et vitae suae illud redemat

I curse him who has stolen, who has robbed Demiorix [or 'who will steal, will rob Demiorix'] from his house. Whoever (stole his) property, the god is to find him. Let him buy it back with his blood and his own life.

(Tomlin 1988: 235)

The text on Tablet no. 94, a 'sanction against perjury', was written ante factem and represents an oath, rather than a curse. I give its concluding section:

... quicumque illie periuraverit deae Suli faciat [corrected by Tomlin to facias] illum sanguine suo illud satisfacere.

(Tomlin 1988: 226)

I propose to translate this as 'whosever will perjure himself the goddess $\mathrm{Sulis}^{7}$ should make ${ }^{8}$ satisfaction by his own blood'.

But Basilia of no. 97 uses the simple perfect:

Basilia donat in templum Martis anilum argentum si servus si liber tamdiu silverit vela liquid de hoc noverit ut sanguine et liminibus et omaibus membris congiguratur vel etiam intestinus excomesis omnibus habeat is qhi anilum involavit...

Basilia gives <in> to the temple of Mars (her) silver ring, that so long as (someone), whether slave or free, keeps silent or knows anything about it, he may be accursed in (his) blood and eyes and every limb, or even have all (his) intestines quite eaten away, if he has stolen the ring...

(Tomlin 1988: 231)

\footnotetext{
${ }^{7}$ The use of dative instead of the nominative is a common mistake influenced by an idiom addressed to Sulis.

${ }^{8}$ Optative by sense, conjunctivus.
} 
BRITISH AND ROMAN NAMES FROM THE SULIS-MINERVA TEMPLE

Tablet no. 5 also provides a very simple example of the loss of an object. In this case a man with the problematic name [...]ocimedis, which could be 'Docimedis' or, according to Tomlin, a Greek name, has lost his two gloves and writes:

[...]ocimedis perdidit manicilia dua qui illas involavit ut mentes suas perdat et oculos suos in fano ubi destinat

Docimedis has lost two gloves. (He asks) that (the person) who has stolen them should lose his mind and his eyes in the temple where (she) appoints.

(Tomlin 1988: 114)

Thus, I may cautiously hypothesise (cautiously indeed, because the material is too scarce to allow more definite conclusions) that two customs existed: among Romans, belongings were entrusted to slaves or left unattended and, in the event anything was stolen, the deity was invoked in order to secure the return of the belongings and to punish the thief; among Britons, the protection of the deity was sought in advance by 'entrusting' the property in question to her. In this light, Tablet no. 99 (fig. 5) is of particular interest, as it refers not to a theft of portable belongings but rather to keeping an entire house safe:

execro qui involaverit qui ${ }^{9}$ Deomiorix de hospitio suo perdiderit quicumque res deus illum inveniat sanguine et vitae suae illud redemat.

I curse [him] who has stolen [will steal], who has robbed [will rob] Deomiorix from his house. Who will steal [stole his] property, the god is to find him. Let him buy it back, with his blood and his own life.

(Tomlin 1988: 235)

One may suggest that this Briton either wrote or commissioned the protective charm for his nearby house and entrusted its security to Sulis the goddess. The text, like many of its kind, contains multiple grammar mistakes, but is addressed to the same deity as the curse tablets. However, in this particular case, a curse tablet - a classical tabella defixionis - is partially re-worked into a protective amulet. The Briton named Docilianus, who had a typically Celtic genitive patronymic Bruceri and who wrote tablet no. 10 in the Sulis Minerva temple, is, according to Tomlin, the same person who wrote another tablet found at a temple site in today's Uley (12 km west of today's Lidney and 35 $\mathrm{km}$ north of Bath). The temple, built in the early $2^{\text {nd }}$ century AD and dedicated to Mercury, was also part of a Romanised area, and, in the course of archaeological research undertaken in the late 1970s, it too yielded many curse

\footnotetext{
${ }^{9}$ Probably quid (=quod). See Adams 1992: 3 for an analysis of specific vocabulary and typical grammar mistakes found in the Bath tablets.
} 
tablets, some of which referred to thefts. Yet, unlike those found in the Sulis thermae, these tablets are mainly about stealing or harming livestock. Tomlin believes the 'Docilinus' mentioned in Tablet No. 43 to be identical with the 'Docilianus' from Bath (both names are actually Romanised forms of the Celtic name Docca). Both texts are written in either identical or at least very similar calligraphic handwriting and share the same formulae of 'horrible (utmost) death' and 'not allowing to sleep':

deo Mercurio Docilinus [...] Varianus et Peregrina et Sabinianus qui pecori meo dolum malum intulerunt et [...] prolocuntur rogo te ut eos maximo leto adigas nec eis sanitatem nec somnum permittas nisi a te quod mihi administraverint redemerint.

To the god Mercury [from] Docilinus ... Varianus and Peregrina and Sabinianus, who have brought evil harm on my beast and are [...] I ask you that you drive them to the greatest death, and do not allow them health or sleep unless they redeem from you what they have administrated to me.

(Curse Tablets, Uley 43)

However, this particular curse is performed post factum, and its purpose is punishing the suspected evildoers rather than keeping property safe. Notably, the text does not refer to a theft but rather to witchcraft (hardly a real event, from a modern point of view). Therefore, this tablet indicates the suspicious and vengeful nature of this (apparently well-to-do) Briton who was afraid of somebody's stealing his cloak or hexing his livestock. The second Docilinus tablet names the suspects and addresses the deity. The verb form used by him - intulerunt - is, strictly speaking, a perfect 3 person pl., but one can conjecture that he made no strict distinction between Latin tenses and would use the -erit forms automatically without clear distinction between perfect and future II.

Taking all of this into consideration, what can one make out of the pure name lists (without any comment) which also occur in the findings from the Sulis Minerva temple? This is a challenging issue. Tomlin believed them to be the names of suspects or adversaries (Hassall and Tomlin 1987: 363), but I do not believe it is possible to accept this interpretation with any certainty. They could well have been the names of victims (interestingly, they are not provided with matronymics) or simply the names of people being cursed (lists of this kind also occur in Roman mainland), or, like graffiti found in Christian churches, the names of those who needed help from the goddess. The only certain fact is that all of them addressed the deity. 


\section{No. 18 - a British text?}

An artefact standing apart from all findings is Tablet no. 18 (fig. 6), which differs from other tablets in its material and shape. It is a bronze disc-shaped object about 35 to $39 \mathrm{~mm}$ in diameter, having a kind of loop along its edge. The text of the inscription goes perpendicular to the loop, which seems to rule out the possibility that the disk was worn like a pendant. The inscription is in Latin majuscule and the handwriting is quite poor, which suggests that its author did not possess the routine skills of literacy. In Tomlin (1987) the text was reconstructed as follows:

\section{ADIXOUI / DEIANA / DEIEDA / ANDAGIN / UINDIORIX / CUAMIIN / AI}

Without giving specific linguistic details, Tomlin identified it as "a Celtic text transcribed by Roman letters" (Tomlin 1987: 24). It was then reinterpreted by P.Y. Lambert:

\section{ADIXOVI / DEVINA / DEIEDA (?) / ANDAGIN / VINDIORIX / CVAMII(?)NAI(?)}

What is certain is the name of the author (or of the client) - Windiorix, a typical Celtic name, clearly made up of two elements, windo- 'white' or 'fair' (Schmidt 1957: 295) or wend- > wind- 'kin, family' (Delamarre 2007: 236) and rix 'king'. The preceding word andagin, as Lambert convincingly demonstrates, can be related to Gaulic andogna, which occurs in a Larzac tablet with the meaning 'local', indicating a female local inhabitant (Lambert 2002: 305; see also Delamarre 2003: 48) ${ }^{10}$. The rest of the words are more difficult to decipher. Lambert interprets the first word as a two-word combination, ad Ixovi, reading the latter as a hydronym (unattested otherwise; cf., however, the hydronym Dexsiva 'dexter, right' cited in his work, which was the name of a river in Gaul, Vaucluse). Devina could be also linked to Celtic hydronyms such as Deva, Devona, the names of rivers or springs dedicated to deities. Dieda (if it is read correctly) is undecipherable. The final word cvamiinai (barely legible) is interpreted by Tomlin as Windiorix' patronymic and by Lambert as a distorted Latin commendat '[he] commands'.

A probable interpretation of this text is that it is a message recording that a local person called Windiorix is entrusting something to somebody near a sacred spring (which is consistent with the location in which the tablet was found). Yet, unlike other tablets found in thermae, this particular one does not specify what exactly is being entrusted or to whom. Perhaps, the very fact that

\footnotetext{
${ }^{10}$ Arguably, this interpretation is not the only possible one (cf. Sims-Williams 2007: 17).
} 
something is being entrusted to Sulis is implied by default, and the absence of the object's name in the text is readily explicable given that the tablet would be tagged by its loop to the object deposited in the changing-room. This would allow the tablet to be used more than once. The message, therefore, was formed by both the tablet and the object together. Cf. the Gaulish votive inscription L-133 (fig. 7): DOIROS SEGOMARI IEVRV ALISANV (Lambert 2002: 351-54), 'Doiros (son) of Segomar dedicated to the god of Alesia', inscribed on the handle of a bronze dipper (or saucepan). The dipper itself is the object implied in the clausa, from where the actual grammatical object (the word for 'dipper') is omitted, and therefore makes up part of the message.

Moreover, I would suggest that the text in Tablet no. 18 was addressed both to the goddess and the potential thief who, seeing the owner's inscription, was expected to understand that the clothing item was protected by the deity and so would be dissuaded from stealing it. This kind of pragmatics might also have been shared by other texts with British names (cited above). The tablet placed over the clothing item might have been expected to convey a message not only to Sulis Minerva but also to the people seeing it. What is notable is the usage of verb forms in the threats listed in the texts which, according to my analysis, can be categorised as 'preventive'. Thus, two models of invocation could possibly be deduced: (1) 'may the one who has stolen $\mathrm{X}$ be punished by you, the goddess' (probably Latin); (2) 'the one who steals $\mathrm{X}$ will be punished by the goddess' (probably British).

\section{Conclusion}

The title of my paper was 'Two solutions to an old problem'. The problem is not a linguistic problem, but a problem as old as time - stealing. What should be done with the thief and how can property be kept safe? I suppose that what we see here is a difference of a worldview. A superstitious Roman believed that, even when his cloak had been stolen, his letter addressed to the goddess would immediately affect the thief, who would feel this fact and, being equally superstitious, would return the object to its owner. Britons seem to have trusted Sulis' power less, or, at least, they believed that an extra indirect message to possible thieves would guarantee the safety of the items entrusted to the goddess just as well. 


\section{References}

\section{Printed Sources}

Adams, J.N., 1992, 'British Latin: the Text, Interpretation and Language of the Bath Curse Tablets', Britannia 23, 1-26.

Audollent, A., 1904, Defixionum tabellae quotquot innotuerunt tam in Graecis orientis quam in totius occidentis partibus praeter Atticas in Corpore inscriptionum Atticarum editas, Luteciae.

Cunliffe, B.W., 1995, Book of Roman Bath, Bath, London: B.T.Batsford, English Heritage.

Delamarre, X., 2003, Dictionnaire de la langue gauloise. Une approche linguistique du vieux-celtique continental, Paris: Éditions errance.

Delamarre, X., 2007, Noms de personnes celtiques, Paris: Édition errance.

Gager, J.G., 1992, Curse Tablets and Binding Spells from the Ancient World, New York - Oxford: Oxford University Press.

Hassall, M.W.C., Tomlin, R.S.O., 1987, 'Inscriptions / Roman Britain in 1986', Britannia 18, 360-77.

Jordan, D.R., 1985, 'A Survey of Greek Defixiones not included in the Special Corpora', Greek, Roman and Byzantine Studies 26, 151-97.

Kagarov, E.G., 1918, Греческие таблички с проклятиями (defixionum tabellae) [Greek curse tablets], Harkov.

Lambert, P.Y., 2002, Recueil des inscriptions Gauloises (RIG), vol. II, f.2 textes Gallo-Latins sur instrumentum, Paris: CNRS.

Mees, B., 2009, Celtic Curses, Woodbridge: The Boydell Press.

Mikhailova, T., 2006, 'On the Function of Name in Irish and Slavonic Written Incantation Tradition', in: Mac Mathúna, S., and Fomin M., eds., Parallels between Celtic and Slavic. Proceedings of the First International Colloquium of Societas Celto-Slavica held at the University of Ulster, Coleraine: The Stationary Office, 163-74.

Poznanskij, N., 1917, Заговоры. Опыт исследования происхождения и развития заговорных формул [Essay on the study of genesis and development of charms formulae], Petrograd (repr. Moscow: Indrik, 1995).

Salway, P., 1993, The Oxford Illustrated History of Roman Britain, Oxford: Oxford University Press.

Schmidt, K.H., 1957, Die Komposition in Gallischen Personennamen, Tübingen: Max Niemer Verlag.

Sims-Williams, P., 2007, 'Common Celtic, Gallo-Brittonic and Insular Celtic', in: P. Sims-Williams, Studies on Celtic Languages before the Year 1000, Aberystwyth: CMCS Publications. 
Tomlin, R.S.O., 1988, The Curse Tablets, in: Cunliffe B., ed., The Temple of Sulis Minerva at Bath. Vol. 2: The Finds from the Sacred Spring, Oxford: Oxford University Committee for Archeology, 59-277.

Tomlin, R.S.O., 1987, 'Was ancient British Celtic ever a written language? Two texts from Roman Bath', The Bulletin of the Board of Celtic Studies, 34, 18-25.

Toporov, V.N., 1993, 'Об индоевропейской заговорной традиции (избранные главы)' [On Indo-European charm tradition (selected papers)], in: Ivanov V.V., Sveshnikova T.V., eds., Исследования в области балтославянской духовной культуры. Заговор [Studies in Balto-Slavonic cultures. Charms], Moscow: Nauka, 3-103.

Versnel, H.S., 1991, 'Beyond Cursing: The Appeal to Justice in Judicial Prayers', in: Faraone C. A. and Obbnik, D., eds., Magika Hiera. Ancient Greek Magic and Religion, Oxford: Oxford University Press.

\section{Electronic sources}

Bowman, A.K., Brady, J.M., Tomlin, R.S.O., Thomas, J.D. A Corpus of Writing-Tablets from Roman Britain, http:www.csad.ox.ac.uk/rib/ribiv/ jp4.htm, accessed 28/09/2011.

Curse Tablets of Roman Britain, http://curses.csad.ox.uk/4Dlink2/, accessed 12/01/2012.

Figures

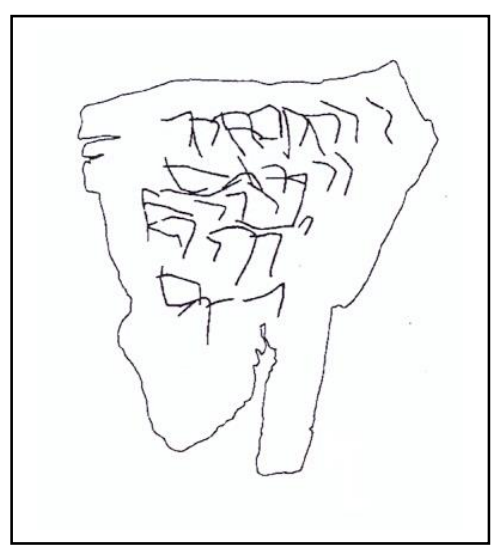

Fig. 1. Inscription no. 113.

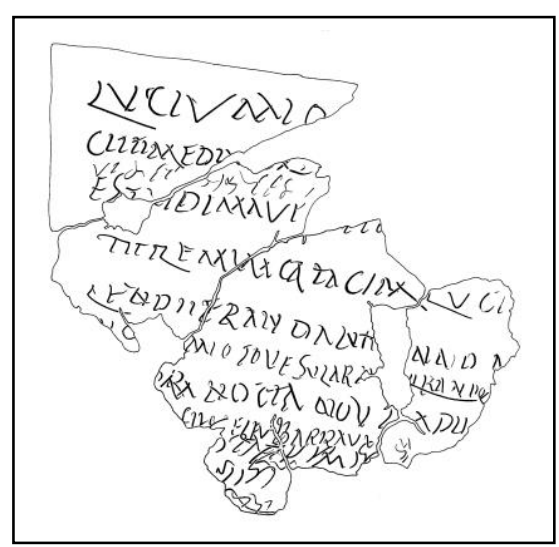

Fig. 2. Inscription no. 14. 


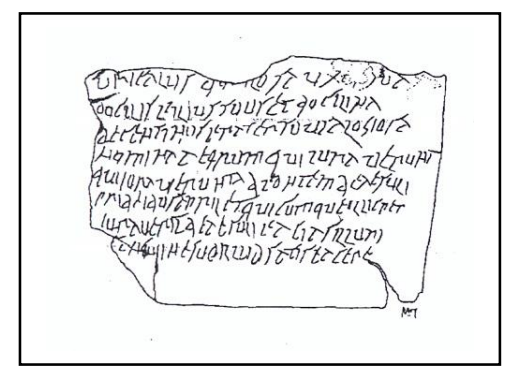

Fig. 3. Inscription no. 94.

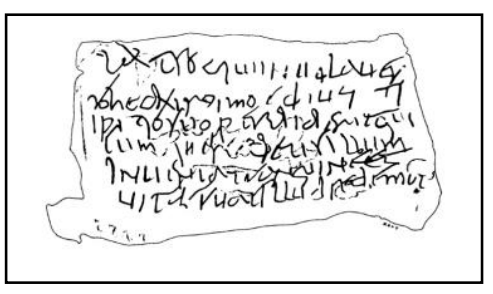

Fig. 5. Inscription no. 99.

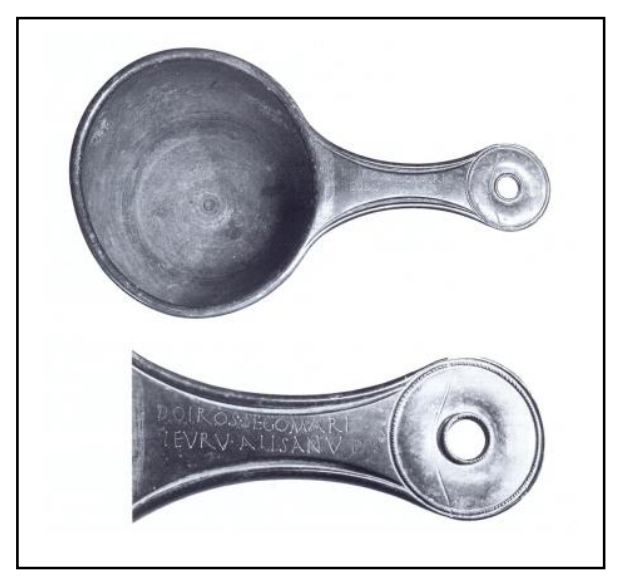

Fig. 7. Inscription L-133.

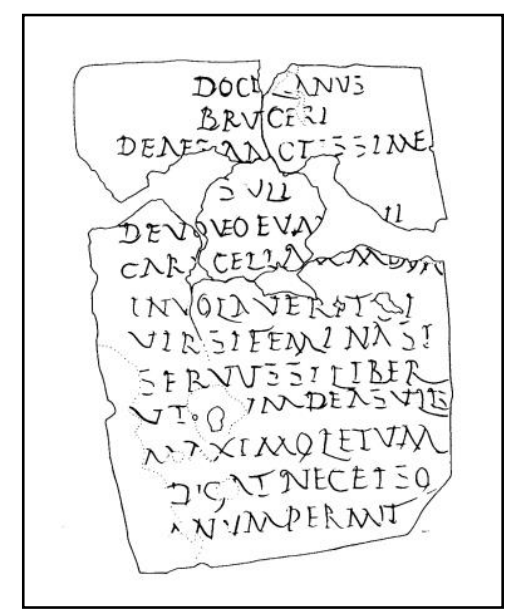

Fig. 4. Inscription no. 10.

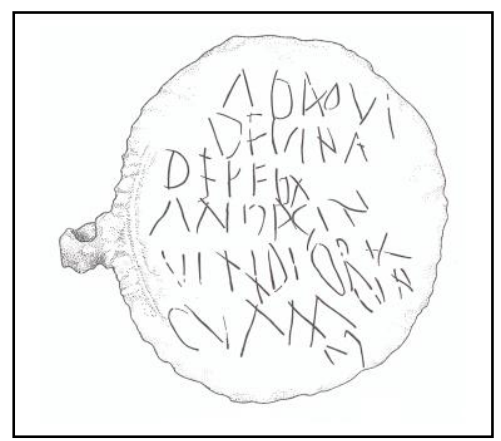

Fig. 6. Inscription no. 18. 